\title{
Zonation and soil factors of salt marsh halophyte communities
}

\author{
Jeom-Sook Lee ${ }^{1}$, Jong-Wook Kim ${ }^{4}$, Seung Ho Lee ${ }^{2}$, Hyeon-Ho Myeong ${ }^{3}$, Jung-Yun Lee ${ }^{4}$ and Jang Sam Cho ${ }^{5}$
}

\begin{abstract}
Background: The structures and soil factors of Suaeda glauca-Suaeda japonica zonal communities and Phragmites australis-S. japonica zonal communities were studied in salt marshes of west and south coasts of South Korea to provide basic data for coastal wetland conservation and restoration.

Results: S. glauca community mean length was $67 \mathrm{~m}$ and S. japonica community mean length was $567 \mathrm{~m}$ in zonal communities, and P. australis and S. japonica community mean length were $57 \mathrm{~m}$ and $191 \mathrm{~m}$ in zonal communities. Regarding the electrical conductivity, sodium content, and clay contents in Upnae-ri, Shinan-gun, there were significant differences among zonal communities at significance level of 0.05 for two-sided $t$ test. However, other factors were not significantly different.
\end{abstract}

Conclusions: The results indicate that multiple factors such as electronic conductivity, total nitrogen level, clay, and sodium might play important roles in the formation of zonal plant communities of salt marshes.

Keywords: Zonation, Salt marsh plant, Soil factor, Suaeda glauca, S. japonica, Phragmites australis

\section{Background}

Zonal distribution of higher plants in salt marshes has been studied extensively for over a century. However, mechanisms of generating the segregation of salt marsh plant species are poorly understood (Caçador et al. 2007; Emery et al. 2001). In order to explain plant zonation, shore height is frequently used as an indicator of abiotic gradient in intertidal ecosystems. This is based on the implicit assumption that shore height is directly correlated with inundation frequency and/or duration (Bockelmann et al. 2002; Sánchez et al. 1996). The objective of this study was to determine structures of zonal communities and factors that might control salt marsh plant patterns and zonations.

\section{Methods}

The structures and soil factors of two zonal community types of South Korea were monitored and can be used as basic data for conservation and restoration of coastal wetland ecosystems (Fig. 1). Six Suaeda glauca-Suaeda japonica zonal communities (Table 1, No. 1-6 in 1998) and five Phragmites australis-S.

\footnotetext{
* Correspondence: keco@mokpo.ac.kr

${ }^{4}$ Department of Biological Science, Mokpo National University, Muan-gun 58554, South Korea

Full list of author information is available at the end of the article
}

japonica zonal communities (Table 1, No. 1 in 1998, No. $2-3$ in 2005 , No. 5-6, 2015) were sampled from the west coast to the south coast of South Korea.

\section{Results and discussion}

S. glauca community mean length was $67 \mathrm{~m}$ and S. japonica community mean length was $567 \mathrm{~m}$ in zonal communities, and $P$. australis community mean length was mean $57 \mathrm{~m}$ and $S$. japonica community mean length was $191 \mathrm{~m}$ in zonal communities (Table 1). S. glauca community was found in Unpo-ri, Songhyun-ri, and Chulpo-ri. The community height was $70-80 \mathrm{~cm}$. Its coverage in study areas was $70-80 \%$. The S. japonica community was found in both S. glauca-S. japonica and $P$. australis-S. japonica zonal communities. Its community height was $35-45 \mathrm{~cm}$. Its coverage in study areas was 85-100\%. The area of salt marshes in Chulpo-ri and Sinduk-ri was $4-5 \mathrm{~km}^{2}$. P. australis communities were found in Woopo-ri, Nongjoo-ri, and Dongkeom-ri. Community height was $64-125 \mathrm{~cm}$ with coverage of $85-100 \%$.

Soil factors in S. glauca, S. japonica, and P. australis communities of Upnae-ri, Shinan-gun, are shown in Fig. 2. Electrical conductivity \pm SE in S. glauca, S. japonica, and P. australis communities were $1.38 \pm 0.0015$, 


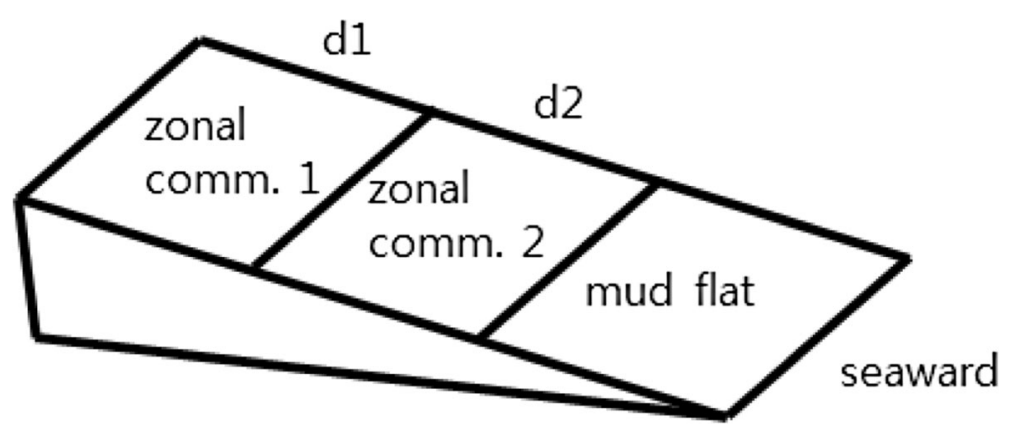

Fig. 1 The first community length of occupation $(d 1, m)$ and second community length of occupation $(d 2, m)$ in salt marsh

$1.28 \pm 0.0045$, and $1.01 \pm 0.0055 \mathrm{mS} / \mathrm{cm}$, respectively ( $n$ $=10$ ). Total nitrogen \pm SE in S. glauca, S. japonica, and $P$. australis communities were $0.21 \pm 0.0026,0.55 \pm$ 0.0026 , and $0.69 \pm 0.0025 \mathrm{mg} / \mathrm{g}$, respectively $(n=10)$. Higher total nitrogen level in S. japonica community than that in S. glauca community might be due to higher density in S. japonica community. Higher total nitrogen level in $P$. australis community might be due to higher biomass in $P$. australis community. Total phosphate \pm SE in S. glauca, S. japonica, and P. australis communities were $0.05 \pm 0.0008, \quad 0.04 \pm 0.0009$, and $0.04 \pm$ $0.0005 \mathrm{mg} / \mathrm{g}$, respectively $(n=10)$. Such slight difference might be due to dilution of inland and coastal wastewater by tide. Sodium contents \pm SE in S. glauca, S. japonica, and $P$. australis communities were $15.3 \pm 0.0137,12.3 \pm$ 0.0052 , and $5.8 \pm 0.0104 \mathrm{mg} / \mathrm{g}$, respectively $(n=10)$. Clay content \pm SE in S. glauca, S. japonica, and $P$. australis communities were $26.0 \pm 0.0344,25.0 \pm 0.0446$, and $8.0 \pm$ $0.0274 \mathrm{mg} / \mathrm{g}$, respectively $(n=10)$. Regarding the electrical conductivity, sodium content, and clay contents in both $S$.
glauca-S. japonica and P. australis-S. japonica communities and total phosphate in S. glauca-S. japonica community in Upnae-ri, Shinan-gun, there were significant differences among zonal communities at significance level of 0.05 for two-sided $t$ test. However, there were little differences in total phosphate levels.

\section{Conclusions}

Halophyte distributions are related to multiple reactions of flooding and salinity concentrations (Benito et al. 1990; Caçador et al. 2007; Mert and Varder 1977). In South Korea, halophyte distributions have been determined for soil-water relation and soil texture (Ihm et al. 2007; Rogel et al. 2001) as well as flooding frequency (Lee 1990). A combination of multiple factors such as flooding, soil salinity, and competition have been suggested to play important roles in the formation of zonal plant communities in salt marshes (Pennings and Callaway 1992; Silvestri et al. 2005).

Table 1 Zonal community name, first community length of occupation, second community length of occupation (d1 and d2, m), locations of six Suaeda glauca-S. japonica, and five Phragmites australis-S. japonica zonal communities

\begin{tabular}{|c|c|c|c|}
\hline Zonal community name & First community length d $1(\mathrm{~m})$ & Second community length $d 2(m)$ & Locations \\
\hline Suaeda glauca-S. japonical & 67 & 990 & Kimje-gun Unpo-ri \\
\hline Suaeda glauca-S. japonica2 & 100 & 100 & Kimje-gun Sopo-ri \\
\hline Suaeda glauca-S. japonica3 & 33 & 462 & Buan-gun Songhyun-ri \\
\hline Suaeda glauca-S. japonica4 & 100 & 627 & Buan-gun Chulpo-ri \\
\hline Suaeda glauca-S. japonica5 & 67 & 924 & Kochang-gun Sinduk-ri \\
\hline Suaeda glauca-S. japonica6 & 33 & 297 & Kochang-gun Wolsan-ri \\
\hline Mean \pm SD & $67 \pm 30$ & $567 \pm 350$ & \\
\hline Phragmites australis-S. japonical & 33 & 231 & Yonggwang-gun Hasa-ri \\
\hline Phragmites australis-S. japonica2 & 55 & 210 & Gangwha-gun Dongkeom-ri \\
\hline Phragmites australis-S. japonica3 & 17 & 118 & Bosung-gun Jeonil-ri \\
\hline Phragmites australis-S. japonica4 & 144 & 216 & Suncheon-gun Nongjoo-ri \\
\hline Phragmites australis-S. japonica5 & 36 & 180 & Buan-gun Woopo-ri \\
\hline Mean \pm SD & $57 \pm 51$ & $191 \pm 45$ & \\
\hline
\end{tabular}



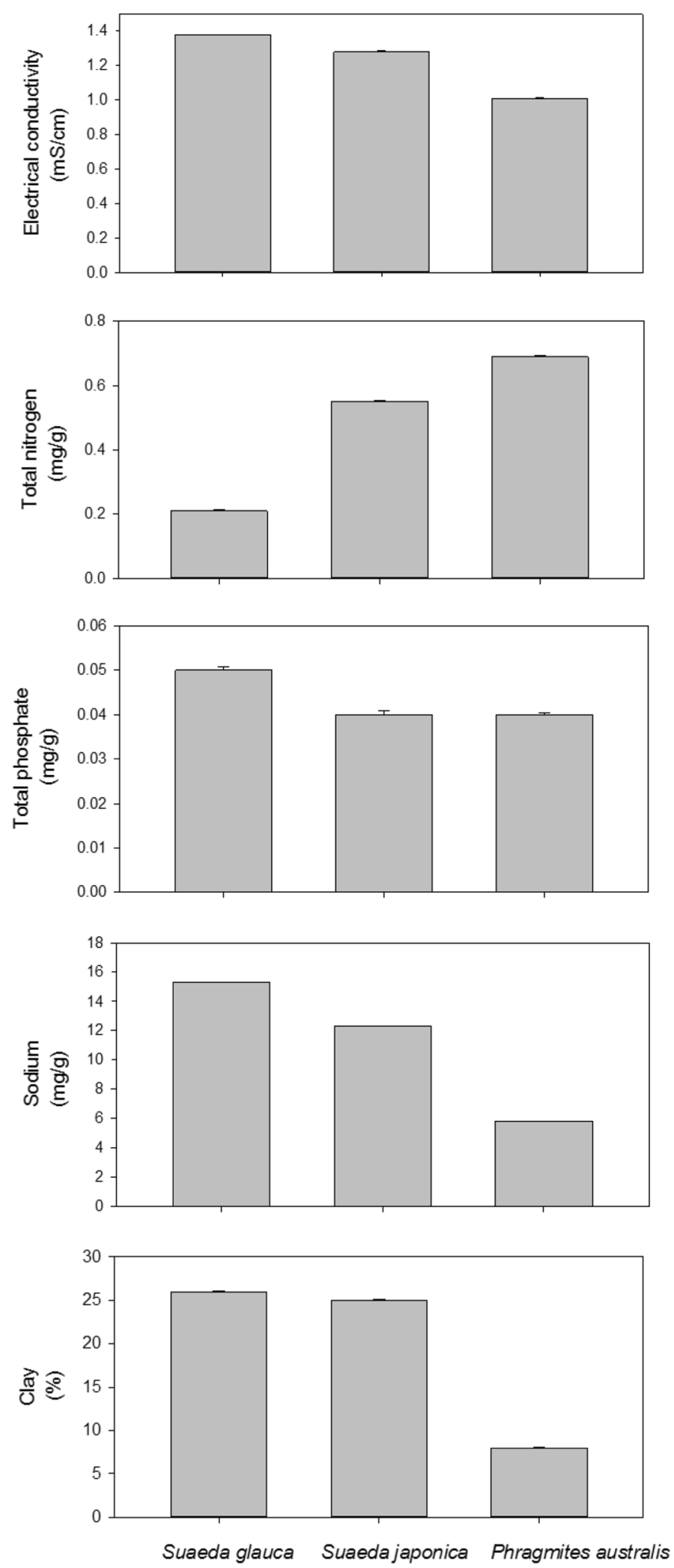

Fig. 2 Electrical conductivity, total nitrogen, total phosphate, sodium, and clay contents (mean \pm SE) in S. glauca, S. japonica, and P. australis communities in salt marshes of Upnae-ri, Shinan-gun 


\section{Acknowledgements}

Emeritus Professor Byung-Sun Ihm deserves to be acknowledged for his ideas and comments on the manuscript at Mokpo National University, South Korea.

\section{Funding}

This research was funded with resources from Mokpo National University.

\section{Availability of data and materials}

Please contact author for data requests.

\section{Authors' contributions}

The study was designed by JSL and JWK. SHL, HHM, and JYL collected and analyzed the data. SHL has helped in the statistical analysis of the data. JWK and SHL has drafted the manuscript. All authors approved the final manuscript.

\section{Competing interests}

The authors declare that they have no competing interests.

\section{Consent for publication}

Not applicable.

Ethics approval and consent to participate

Not applicable.

\section{Author details}

'Department of Biology, Kunsan National University, Gunsan 54150, South Korea. ${ }^{2}$ Marine \& Environmental Research Laboratory, Ansan 15486, South Korea. ${ }^{3}$ Division of Ecosystem Research, National Park Research Institute, Wonju 26441, South Korea. ${ }^{4}$ Department of Biological Science, Mokpo National University, Muan-gun 58554, South Korea. ${ }^{5}$ Division of Ecological Assessment, National Institute of Ecology, Seocheon 33657, South Korea.

Received: 2 February 2016 Accepted: 1 July 2016

Published online: 24 October 2016

\section{References}

Benito, I, Agirre, A, \& Onaindia, M (1990). Zonation of halophytic vegetation along a tide exposure gradient and associated processes. Anales de Biologia, 16, 163-175.

Bockelmann, AC, Bakker, JP, Neuhaus, R, \& Lage, J (2002). The relation between vegetation zonation, elevation and inundation frequency in a Wadden Sea salt marsh. Aquatic Botany, 73, 211-221.

Caçador, l, Tibério, S, \& Cabral, HN (2007). Species zonation in Corroios salt marsh in the Tagus estuary (Portugal) and its dynamics in the past fifty years. Hydrobiologia, 587, 205-211.

Emery, NC, Ewanchuk, PJ, \& Bertness, MD (2001). Competition and salt-marsh plant zonation: stress tolerators may be dominant competitors. Ecology, 82, 2471-2485.

Ihm, B-S, Lee, J-S, Kim, J-W, \& Kim, J-H (2007). Coastal plant and soil relationships in the southwestern coast of South Korea. J Plant Biol, 50, 331-335.

Lee, J-S (1990). On establishment of halophytes along tidal level gradient at salt marshes of Manhyong and Dongjin river estuaries. South Korea, Seoul National University.

Mert, HH, \& Varder, Y (1977). Salinity, osmotic pressure, and transpiration relationships of Salicornia herbaceae in its natural habitats. Phyton, 18, 71-78.

Pennings, SC, \& Callaway, RM (1992). Salt marsh plant zonation: the relative importance of competition and physical factors. Ecology, 73, 681-690.

Rogel, JÁ, Silla, RO, \& Ariza, FA (2001). Edaphic characterization and soil ionic composition influencing plant zonation in a semiarid Mediterranean salt marsh. Geoderma, 99, 81-98.

Sánchez, JM, Izco, J, \& Medrano, M. (1996). Relationships between vegetation zonation and altitude in a salt-marsh system in northwest Spain. Journal of Vegetation Science, 7, 695-702.

Silvestri, S, Defina, A, \& Marani, M (2005). Tidal regime, salinity and salt marsh plant zonation. Estuar Coast Shelf S, 62, 119-130.

\section{Submit your next manuscript to BioMed Central and we will help you at every step:}

- We accept pre-submission inquiries

- Our selector tool helps you to find the most relevant journal

- We provide round the clock customer support

- Convenient online submission

- Thorough peer review

- Inclusion in PubMed and all major indexing services

- Maximum visibility for your research

Submit your manuscript at www.biomedcentral.com/submit
Biomed Central 